\title{
The Muslim Religious Minority in the Republic of Serbia and Its Impact on the Bilateral Relations of the Republic of Serbia with Neighboring States
}

\section{Introduction}

The states situated on the Balkan Peninsula are characterized by a significant diversity of people living there, especially in ethnic terms, but also in terms of language and religion. Ethnic, linguistic and religious diversity implies specific socio-political consequences that have a significant impact on the policies of Balkan states. As a consequence, the authorities of states from the Balkan region are forced to take into account in their politics the various needs of ethnic, linguistic and religious minorities. In addition, in the interests of the representatives of their ethnic, language and religious groups, neighboring states often take action, where representatives of a specific group are of the majority. As the title suggests, in this article the author decided to analyze the influence of the Muslim religious minority on relations between the Republic of Serbia and neighboring states.

For a proper analysis of the chosen subject, the main content of the article has been divided into three parts. In the first part, the author described the essential characteristics of the Muslim religious minority in the Republic of Serbia relevant to the subject of the article, such as the number of representatives of the Muslim minority in the country, membership of Islamic trends, and religious organizations representing Muslims in the Republic of Serbia. In the second part, the author described the deployment of Muslims in individual administrative units of the Republic of Serbia, using data published after the 2011 census. In the third part, the author analyzed the factors shaping the relations between the Republic of Serbia and neighboring countries, such as political activity of Muslims within their ethnic communities, actions taken by Muslim countries and Muslim organizations from outside the Balkans region and acts of violence committed by Kosovo Albanians.

\section{Muslim Religious Minority in the Republic of Serbia}

According to data collected as part of the census conducted in 2011, during which religious membership was also asked, the Muslim religious minority living in the Republic of Serbia (excluding Kosovo) was 222,828 people $-3.10 \%$ 
of the total population of the country (Republic of Serbia was inhabited by $7,186,862$ people $)^{1}$. However, the official number of Muslims living in the Republic of Serbia in 2011 should be considered slightly undervalued, because - according to their right - 220,735 people did not answer the question about religion, while in turn no answers were obtained from another 99,714 people - respectively $3.07 \%$ and $1.39 \%$ of the total population of the Republic of Serbia ${ }^{2}$. Moreover, Muslim organizations themselves have contributed to the very likely underestimate of the official number of Muslims in the Republic of Serbia. These organizations called for a boycott of the census, because in their opinion there were numerous irregularities during the preparation of this type of statistics ${ }^{3}$.

Muslims in the Republic of Serbia are mostly Hanafites - thus they represent one of the four main Sunni schools of Islamic law. There are also small Sufi Khanqahs ${ }^{4}$ in Novi Pazar. Since the 1990s, Wahhabis who are Islamic fundamentalists have been active in the Republic of Serbia. The exact number of Wahhabis is difficult to determine, in 2014 they ran two mosques in Novi Pazar. In 2014, about 190 mosques were located in the Republic of Serbia, of which about 120 of them were in Sandžak, while about 60 in the southern districts of this state, as well as in larger cities such as Belgrade, Niš and Subotica. In Vojvodina there were eight mosques without minarets, because the authorities of the Autonomous Province of Vojvodina do not give consent to their construction. A significant number of existing mosques in the Republic of Serbia came into existence only after the disintegration of the Socialist Federal Republic of Yugoslavia 5 .

The main organization bringing together and representing Muslims living in the Republic of Serbia - with the exception of Kosovo - is established in 2007 Islamic Community in Serbia (Исламска заједница у Србији/Islamska zajednica $u$ Srbiji), with seat in Novi Pazar. The Islamic Community in Serbia was established as a result of the transformation of the Islamic Community in Sandžak (Исламска заједница у Санџаку/Islamska zajednica u Sandžaku), which operated since 1993. The Grand Mufti of the Islamic Community in Serbia

\footnotetext{
${ }^{1}$ According to data from July 2018, the Republic of Serbia, with the exception of Kosovo, was inhabited by 7,078,110 people. The World Factbook, Serbia, https:/www.cia.gov/library/publications/the-world-factbook/geos/ri.html, retrieved 17.12.2018.

${ }^{2}$ Попис становништва, домаћинстава и станова 2011. у Републищи Србији, број 4, Становништво. Вероисповест, матерни језик и национална припадност. Подаци по општинама и градовима, Република Србија Републички завод за статистику, Београд 2013 = 2011 Census of Population, Households and Dwellings in the Republic of Serbia, No. 4, Population, Religion, mother tongue and ethnicity. Data by municipalities and cities, Statistical Office of the Republic of Serbia, Belgrade 2013, p. 13.

${ }^{3}$ A. Pramenković, Serbia, [in:] Yearbook of Muslims in Europe, Vol. 6, eds J.S. Nielsen, S. Akgönül, A. Alibašić, E. Račius, Leiden-Boston 2014, pp. 530-531.

${ }^{4}$ Khanqah is a kind of monastery, the seat of the Sufi brotherhood.

${ }^{5}$ Ibidem, p. 533.
} 
ince its inception is Muamer Zukorlić (Муамер Зукорлић). The organizational structure consists of Muftiship of Belgrade (with seat in Belgrade), Muftiship of Novi Sad (with seat in Novi Sad), Muftiship of Preševo (with seat in Preševo) and Muftiship of Sandžak (with seat in Novi Pazar). According to the decision of the Islamic Community itself in Serbia, it is part of the Islamic Community of Bosnia and Herzegovina (Исламска заједница у Босни и Херцеговини /Islamska zajednica u Bosni i Hercegovini), which gives religious relations an interstate character and is therefore relevant from the perspective of relations between the Republic of Serbia and Bosnia and Herzegovina. On the territory of the Republic of Serbia, there is also a parallel competitive Islamic Community of Serbia (Исламска заједница Србије/Islamska zajednica Srbije), with a seat in Belgrade. The structure of this religious organization consists of Muftiship of Preševo (with seat in Preševo), Muftiship of Raška (with seat in Novi Pazar) and Muftiship of Serbia (with seat in Belgrade). At the head of the Islamic Community of Serbia is the Great Mufti Sead Nasufović (Сеад Насуфовић) ${ }^{6}$.

\section{Muslims in the Administrative Divisions of the Republic of Serbia}

In the administratively separated City of Belgrade, only in the municipality of Palilula, the population of Muslims has exceeded 5\%. The percentage of Muslims there was $5.18 \%$, and it was inhabited by a total of 8,985 people of Islam. On the scale of the total population of the capital of the Republic of Serbia, their number of Muslims was only $1.92 \%$ - 31,914 people out of 1,659,440 inhabitants of Belgrade in 2011. Statistical data for the remaining municipalities in Belgrade are presented in the Table 1.

Table 1. Muslim Population in the City of Belgrade

\begin{tabular}{|l|c|}
\hline \multicolumn{1}{|c|}{ Municipality } & Muslim population (\% of total population) \\
\hline Palilula & $8,985(5.18 \%)$ \\
\hline Zemun & $7,028(4.18 \%)$ \\
\hline Surčin & $1,237(2.82 \%)$ \\
\hline Novi Beograd & $4,315(2.01 \%)$ \\
\hline Čukarica & $3,219(1.78 \%)$ \\
\hline Savski venac & $433(1.11 \%)$ \\
\hline
\end{tabular}

${ }^{6} \mathrm{~J}$. Duda, Islamic community in Serbia - the Sandžak case, [in:] Muslims in Poland and Eastern Europe. Widening the European Discourse on Islam, ed. K. Górak-Sosnowska, Warszawa 2011, pp. 329-330; A. Pramenković, op. cit., pp. 532-533. More about it: S. Barišić, Muslims in the Balkans: Problems of (Re)Institutionalization and Transformation of Identity, [in:] Islam at the Balkans in the Past, Today and in the Future, eds D.B. Đorđević, D. Todorović, L. Mitrović, Niš 2007. 


\begin{tabular}{|l|c|}
\hline \multicolumn{1}{|c|}{ Municipality } & Muslim population (\% of total population) \\
\hline Stari grad & $504(1.04 \%)$ \\
\hline Zvezdara & $1,550(1.02 \%)$ \\
\hline Mladenovac & $511(0.96 \%)$ \\
\hline Rakovica & $1,018(0.94 \%)$ \\
\hline Grocka & $766(0.91 \%)$ \\
\hline Voždovac & $1,359(0.86 \%)$ \\
\hline Vračar & $430(0.76 \%)$ \\
\hline Barajevo & $141(0.52 \%)$ \\
\hline Sopot & $80(0.39 \%)$ \\
\hline Obrenovac & $190(0.26 \%)$ \\
\hline Lazarevac & $148(0.25 \%)$ \\
\hline Altogether & $31,914(1.92 \%)$ \\
\hline
\end{tabular}

Source: Попис становништва.., број 4, pp. 38-39, 46-47.

In the administrative units of the central part of the Republic in 2011, the highest percentage of Muslims inhabited the Raška District, where the percentage reached $36.38 \%-112,520$ people. The high percentage in the whole of the Raška District had an impact on the Muslim domination in the individual municipalities of the district. In the municipality of Tutin, the percentage of Muslims in the population of this administrative unit was the highest in the entire Republic of Serbia (excluding Kosovo), because it was at the level of $93.79 \%$ (28,220 people). In the city of Novi Pazar, the percentage of Muslims was $82.37 \%$ ( 82,710 people). The high percentage of Muslims living in the municipality of Tutin and the city of Novi Pazar results from the geographic location of these administrative units, because they are located near the border with Kosovo. In the remaining communes of the Raška District, the Muslim population was residual.

The second in terms of the number of Muslims in 2011 was the neighboring Zlatibor District, in the case of which Islam was the religion of $15.61 \%$ of the population (44,742 people). Most of them lived in the municipality of Sjenica - 79.21\% (20,906 people). Subsequently, in terms of the number of Muslims, the municipality of Prijepolje - 44.69\% (16,562 people), the municipality of Priboj $-21.35 \%$ (5,793 people) and the municipality of Nova Varoš $-8.32 \%$ (1,384 peo- 
ple), were placed. Also for these administrative units, the high population of Muslims living in their territory resulted from the border location of the Zlatibor District. Moreover, in the municipalities of this district, which are distant from the border, the number of Muslims only ranged from one to a maximum of 49 people.

The last district in the communes with a significant Muslim population was the Pčinja District. While in terms of this entire administrative unit, Muslims represented only $3.19 \%$ of the total population ( 5,069 people), in the municipalities bordering Kosovo - the municipality of Bujanovac and the municipality of Preševo - they counted for around $1 / 5$ of the population of these administrative units: $22,90 \%$ (4.137 people) and $19.25 \%$ (593 people), respectively. In the remaining municipalities of the Pčinja District, the percentage of people who declared Islam as their religion did not exceed one percent. In the remaining districts of the central part of the Republic of Serbia, the percentage of the Muslim population in relation to the total population was small, and in some cases almost negligible. This is evidenced by the data provided in the Table 2 .

Table 2. Muslim Population in the Central Serbia

\begin{tabular}{|c|c|c|}
\hline District & $\begin{array}{l}\text { Muslim } \\
\text { population } \\
\text { (\% of total } \\
\text { population) }\end{array}$ & Cities and municipalities \\
\hline Raška District & $112,520(36.38 \%)$ & $\begin{array}{l}\text { Tutin }-29,220(93.79 \%) \text {; City of Novi Pazar }-82,710 \\
(82.37 \%) \text {; City of Kraljevo }-532(0.42 \%) \text {; Vrnjačka } \\
\text { Banja - } 30(0.11 \%) ; \text { Raška }-28(0.11 \%)\end{array}$ \\
\hline Zlatibor District & $44,742(15.61 \%)$ & $\begin{array}{l}\text { Sjenica - 20,906 (79.21\%); Prijepolje - 16,562 } \\
(44.69 \%) \text {; Priboj - 5,793 (21.35\%); Nova Varoš } \\
-1,384(8.32 \%) ; \text { Arilje - } 18(0.10 \%) ; \text { Čajetina } \\
-11(0.07 \%) \text { City of Užice }-49(0.06 \%) ; \text { Bajina } \\
\text { Bašta - } 11(0.04 \%) ; \text { Požega - } 7(0.02 \%) ; \text { Kosjerić } \\
-1(0.01 \%)\end{array}$ \\
\hline Pčinja District & $5,069(3.19 \%)$ & $\begin{array}{l}\text { Bujanovac }-4,137(22.90 \%) ; \text { Preševo }-593(19.25 \%) ; \\
\text { Vladičin Han - } 114(0.55 \%) \text {; City of Vranje } \\
-195(0.23 \%) ; \text { Surdulica }-28(0.14 \%) ; \text { Bosilegrad } \\
-2(0.02 \%) ; \text { Trgovište - anyone }\end{array}$ \\
\hline $\begin{array}{l}\text { Braničevo } \\
\text { District }\end{array}$ & $2,905(1.58 \%)$ & $\begin{array}{l}\text { City of Požarevac - 2,817 (3.74\%); Žabari } \\
-37(0.33 \%) ; \text { Golubac - } 11(0.13 \%) ; \text { Žagubica } \\
-12(0.09 \%) ; \text { Petrovac na Mlavi - } 13(0.04 \%) \text {; Veliko } \\
\text { Gradište }-6(0.03 \%) ; \text { Kučevo - } 5(0.03) ; \text { Malo Crniće } \\
-4(0.03 \%)\end{array}$ \\
\hline Bor District & $1,458(1.17 \%)$ & $\begin{array}{l}\text { City of Bor - } 1,338(2.75 \%) \text {; Negotin }-69(0.19 \%) \\
\text { Majdanpek - } 30(0.16 \%) \text {; Kladovo }-21(0.10 \%)\end{array}$ \\
\hline $\begin{array}{l}\text { Podunavlje } \\
\text { District }\end{array}$ & $1,862(0.93 \%)$ & $\begin{array}{l}\text { City of Smederevo - } 1,670(1.54 \%) ; \text { Smederevska } \\
\text { Palanka - } 143(0.28 \%) \text {; Velika Plana - } 49(0.12 \%)\end{array}$ \\
\hline
\end{tabular}




\begin{tabular}{|c|c|c|}
\hline District & $\begin{array}{l}\text { Muslim } \\
\text { population } \\
\text { (\% of total } \\
\text { population) }\end{array}$ & Cities and municipalities \\
\hline Mačva District & $2,225(0.74 \%)$ & $\begin{array}{l}\text { Mali Zvornik - } 472(3.78 \%) ; \text { Krupanj - } 229(1.32 \%) \text {; } \\
\text { City of Loznica - } 724(0.91 \%) ; \text { City of Šabac } \\
-760(0.66 \%) ; \text { Koceljeva }-13(0.10 \%) ; \text { Bogatić } \\
\text { - } 19(0.07 \%) ; \text { Vladimirci - } 8(0.05 \%) ; \text { Ljubovija } \\
\text { - anyone }\end{array}$ \\
\hline Nišava District & $2,654(0.71 \%)$ & $\begin{array}{l}\text { City of Niš }-2,486(0.96 \%) ; \text { Aleksinac }-159(0.31 \%) \text {; } \\
\text { Merošina }-4(0.03 \%) ; \text { Doljevac }-3(0.02 \%) \text {; Svrljig } \\
-2(0.01 \%) \text {; Gadžin Han - anyone; Ražanj - anyone }\end{array}$ \\
\hline $\begin{array}{l}\text { Jablanica } \\
\text { District }\end{array}$ & $815(0.38 \%)$ & $\begin{array}{l}\text { Medveđa }-581(7.81 \%) \text {; Crna Trava }-3(0.18 \%) ; \\
\text { Bojnik - } 16(0.14 \%) \text {; City of Leskovac }-189(0.13 \%) \text {; } \\
\text { Lebane - } 18(0.08 \%) \text {; Vlasotince }-8(0.03 \%)\end{array}$ \\
\hline Toplica District & $334(0.36 \%)$ & $\begin{array}{l}\text { Prokuplje - } 299(0.67 \%) \text {; Kuršumlija }-17(0.09 \%) \text {; } \\
\text { Žitorađa - } 11(0.07 \%) ; \text { Blace }-7(0.06 \%)\end{array}$ \\
\hline $\begin{array}{l}\text { Šumadija } \\
\text { District }\end{array}$ & $730(0.25 \%)$ & $\begin{array}{l}\text { City of Kragujevac - } 665(0.37 \%) ; \text { Aranđelovac } \\
-35(0.08 \%) \text {; Topola }-15(0.07 \%) ; \text { Batočina } \\
-8(0.07 \%) ; \text { Rača }-6(0.05 \%) ; \text { Knić }-1(0.01 \%) ; \\
\text { Lapovo - anyone }\end{array}$ \\
\hline Pirot District & $219(0.24 \%)$ & $\begin{array}{l}\text { Bela Palanka - } 64(0.53 \%) \text {; City of Pirot } \\
-147(0.25 \%) \text {; Dimitrovgrad - } 6(0.06 \%) \text {; Babušnica } \\
-2(0.02 \%)\end{array}$ \\
\hline Zaječar District & $277(0.23 \%)$ & $\begin{array}{l}\text { Boljevac - } 53(0.41 \%) \text {; City of Zaječar }-164(0.28 \%) \text {; } \\
\text { Sokobanja - } 30(0.19 \%) \text {; Knjaževac }-30(0.10 \%)\end{array}$ \\
\hline $\begin{array}{l}\text { Pomoravlje } \\
\text { District }\end{array}$ & $324(0.15 \%)$ & $\begin{array}{l}\text { Despotovac }-67(0.29 \%) ; \text { Svilajnac }-48(0.20 \%) ; \\
\text { Paraćin - } 91(0.17 \%) ; \text { Cuprija }-47(0.15 \%) ; \text { City } \\
\text { of Jagodina }-69(0.10 \%) ; \text { Rekovac }-2(0.02 \%)\end{array}$ \\
\hline Rasina District & $348(0.14 \%)$ & $\begin{array}{l}\text { City of Kruševac }-243(0.19 \%) ; \text { Trstenik }-51 \\
(0.12 \%) ; \text { Brus }-16(0.10 \%) ; \text { Ćicevac }-9(0.09 \%) \\
\text { Varvarin }-14(0.08 \%) ; \text { Aleksandrovac }-15(0.06 \%)\end{array}$ \\
\hline $\begin{array}{l}\text { Moravica } \\
\text { District }\end{array}$ & $157(0.07 \%)$ & $\begin{array}{l}\text { Gornji Milanovac - } 53(0.12 \%) \text {; Lučani }-16(0.08 \%) \text {; } \\
\text { City of Čačak - } 73(0.06 \%) \text {; Ivanjica - } 15(0.05 \%)\end{array}$ \\
\hline $\begin{array}{l}\text { Kolubara } \\
\text { District }\end{array}$ & $69(0.04 \%)$ & $\begin{array}{l}\text { Mionica }-13(0.09 \%) ; \text { City of Valjevo }-44(0.05 \%) \\
\text { Osečina }-5(0.04 \%) ; \mathrm{Ljig}-3(0.02 \%) ; \mathrm{Ub}-3(0.01 \%) \\
\text { Lajkovac }-1(0.01 \%)\end{array}$ \\
\hline Altogether & $162,502(4.52 \%)$ & \\
\hline
\end{tabular}

Source: Попис становништва..., број 4, pp. 40-45, 48-53.

Data obtained during the census in the Autonomous Province of Vojvodina show that among its population the number of Muslims was small, as it was at the level of $0.74 \%$ of the total population (14,206 people). According to detailed 
statistics cited in the table below, a more significant percentage of the Muslim minority occurred only in the religiously diverse municipality of Beočin, in the South Bačka District, because there was a percentage share of Islam professed at the level of $8.74 \%$ of the total population (1,374 people).

Table 3. Muslim Population in the Autonomous Province of Vojvodina

\begin{tabular}{|c|c|c|}
\hline District & $\begin{array}{l}\text { Muslim } \\
\text { population } \\
\text { (\% of total } \\
\text { population) }\end{array}$ & Cities and municipalities \\
\hline $\begin{array}{l}\text { North Bačka } \\
\text { District }\end{array}$ & $3,113(1.67 \%)$ & $\begin{array}{l}\text { City of Subotica - 2,756 (1.95\%); Mali Iđoš } \\
-232(1.93 \%) ; \text { Bačka Topola - } 125(0.38 \%)\end{array}$ \\
\hline $\begin{array}{l}\text { South Bačka } \\
\text { District }\end{array}$ & $6,872(1.12 \%)$ & $\begin{array}{l}\text { Beočin - } 1,374(8.74 \%) \text {; City of Novi Sad }-4,760 \\
(1.39 \%) ; \text { Bač }-198(1.37 \%) ; \text { Bečej }-206(0.55 \%) ; \\
\text { Vrbas - } 114(0.27 \%) ; \text { Bačka Palanka }-98(0.18 \%) ; \\
\text { Bački Petrovac }-24(0.18 \%) \text {; Srbobran }-23(0.14 \%) ; \\
\text { Titel - } 19(0.12 \%) ; \text { Temerin - } 32(0.11 \%) \text {; Sremski } \\
\text { Karlovci - } 9(0.10 \%) \text {; Žabalj - } 15(0.06 \%)\end{array}$ \\
\hline $\begin{array}{l}\text { Central Banat } \\
\text { District }\end{array}$ & $1,537(0.82 \%)$ & $\begin{array}{l}\text { City of Zrenjanin - 1,391 (1.13\%); Sečanj } \\
-41(0.31 \%) ; \text { Novi Bečej - 66 (0.28\%); Nova Crnja } \\
-17(0.17 \%) ; \text { Žitište }-22(0.13 \%)\end{array}$ \\
\hline $\begin{array}{l}\text { South Banat } \\
\text { District }\end{array}$ & $1,310(0.45 \%)$ & $\begin{array}{l}\text { City of Pančevo - } 769(0.62 \%) ; \text { City of Vršac } \\
-253(0.49 \%) ; \text { Kovačica }-100(0.40 \%) ; \text { Kovin } \\
-98(0.29 \%) ; \text { Bela Crkva }-48(0.28 \%) ; \text { Alibunar } \\
-24(0.12 \%) ; \text { Opovo - } 11(0.11 \%) ; \text { Plandište } \\
-7(0.06 \%)\end{array}$ \\
\hline $\begin{array}{l}\text { North Banat } \\
\text { District }\end{array}$ & $404(0.27 \%)$ & $\begin{array}{l}\text { Kanjiža }-119(0.47 \%) \text {; Senta }-80(0.34 \%) \text {; Čoka } \\
-31(0.27 \%) ; \text { Ada }-40(0.24 \%) \text {; Novi Kneževac } \\
-25(0.22 \%) \text {; City of Kikinda }-109(0.18 \%)\end{array}$ \\
\hline $\begin{array}{l}\text { West Bačka } \\
\text { District }\end{array}$ & $380(0.20 \%)$ & $\begin{array}{l}\text { Kula - } 117(0.27 \%) \text {; City of Sombor }-193(0.22 \%) \text {; } \\
\text { Apatin }-38(0.13 \%) \text {; Odžaci }-32(0.11 \%)\end{array}$ \\
\hline Srem District & $590(0.19 \%)$ & $\begin{array}{l}\text { Irig - } 39(0.36 \%) ; \text { City of Sremska Mitrovica } \\
-240(0.30 \%) ; \text { Pećinci }-44(0.22 \%) ; \text { Stara Pazova } \\
-126(0.19 \%) ; \text { Ruma }-65(0.12 \%) ; \text { Inđija } \\
-52(0.11 \%) ; \text { Sid }-24(0.07 \%)\end{array}$ \\
\hline Altogether & \multicolumn{2}{|l|}{$14,206(0.74 \%)$} \\
\hline
\end{tabular}

Source: Попис становништва..., број 4, pp. 38-41, 46-49.

\section{The impact of the Muslim religious minority on relations between the Republic of Serbia and neighboring countries}

The Muslims living in the Republic of Serbia are predominantly of Albanian or Bosniak origin, which is confirmed by the data presented in the 2011 census, which has already been discussed in this article. As a consequence, 
in municipalities where the inhabitants are religiously diverse, they are also ethnically and linguistically diverse, because Muslims also speak Albanian or Bosniak ${ }^{7}$. For this reason, although the religious question has no leading role in relations between the Republic of Serbia and neighboring states, it is inseparable from the influence of the ethnic question on these relations.

From a legal perspective, the constitutional and statutory solutions defining the functioning of the Muslim minority in the Republic of Serbia ${ }^{8}$ should be regarded as beneficial for people professing Islam. Despite this, after 2006, some tensions were not avoided, although they were mainly caused by ethnic factors. Two areas are particularly problematic in this case, because Muslims are a significant minority in their territory, or even because they are the majority, as in the case of several municipalities, excluding Kosovo from the analysis.

The first region in which the problem with ethnic minority took place, whose representatives are Muslims, is Sandžak, which is the territory included in the Raška District. In the Republic of Serbia since 2006 belongs the greater part of Sandžak $\left(4,504 \mathrm{~km}^{2}\right)$, the second part $\left(3,905 \mathrm{~km}^{2}\right)$ is located within the borders of Montenegro. The Sandžak is inhabited by Muslims of Bosniak origin'. The reasons for the tensions in this area were the activities of Bosniak Sandžak's political leaders at the turn of the 20th and 21st centuries, because they wanted to gain greater independence from Belgrade and even gain autonomy. In order to achieve greater independence or autonomy, the Bosniaks of Sandžak established the Bosniac National Council (Бошњачко национално вијеће/Bošnjačko nacionalno vijeće). However, at present the Bosniac National Council is dominated by political parties cooperating with the authorities of the Republic of Serbia ${ }^{10}$.

The second area in which there were problems with the ethnic minority whose representatives are Muslims were the municipality of Bujanovac,

${ }^{7}$ More about it: Попис становништва, домаћинстава и станова 2011. у Републици Србији, број 1, Национална припадност. Подации по општинама и градовима, Република Србија Републички завод за статистику, Београд 2012 = 2011 Census of Population, Households and Dwellings in the Republic of Serbia, No. 1, Ethnicity. Data by municipalities and cities, Statistical Office of the Republic of Serbia, Belgrade 2012, pp. 20-89; Попис становништва..., број 4, pp. 54-69.

${ }^{8}$ Minority rights were included in the Constitution of the Republic of Serbia (Устав Републике Србије/Ustav Republike Srbije), and then extended and clarified in the Act on the Protection of Minorities' Rights and Freedoms (Закон о заштити права и слобода мањина/Zakon o zaštiti prava i sloboda manjina).

${ }^{9} \mathrm{Z}$. Bottlik, Geographical and historical aspects of the situation of Muslim population in the Balkans, „Hungarian Geographical Bulletin” 2009, Vol. 58, No. 4, pp. 272-273.

${ }^{10}$ M. Korzeniewska-Wiszniewska, Polityka etniczna Republiki Serbii wobec wybranych mniejszości po 2009 roku, „Studia Środkowoeuropejskie i Bałkanistyczne” 2016, Vol. XXIV, pp. 170-171; D. Mikucka-Wójtowicz, Sytuacja mniejszości boszniackiej w Sandżaku - wyzwania i problemy, „Sprawy Narodowościowe” 2013, Issue 42, pp. 163-164. 
the municipality of Medveđa and the municipality of Preševo, which form the Preševo Valley, located in the Jablanica District and the Pčinja District. The Preševo Valley is inhabited by Muslims of Albanian origin, which results from the location of the region near the border with Kosovo. Unlike at Sandžak, in the Preševo Valley at the turn of the 20th and 21st centuries, there was a conflict. At that time, the Liberation Army of Preševo, Medveđa and Bujanovac (Ushtria Çlirimtare e Preshevës, Medvegjës dhe Bujanocit) was established there, which was organized along the lines of the Kosovo Liberation Army (Ushtria Çlirimtare e Kosovës). The goal of the Albanians was the administrative connection of the Preševo Valley to the Kosovo. Currently, the situation is much calmer; however, some of the Albanian people did not abandon their plans at the turn of the 20th and 21st centuries. The other political leaders of the Albanians established the Albanian National Council (Национални савет Албанаца/Nacionalni savet Albanaca; Këshilli Kombëtar i Shqiptarëve), as was the case with the Bosniac National Council. The main goal of the Albanian National Council was to integrate the Albanian community with the Serbian community and to include Albanians in the functioning of local and state authorities and institutions ${ }^{11}$.

As part of the analysis of relations between the Republic of Serbia and neighboring states in the context of the Muslim religious minority living in the Republic of Serbia, it should be noted that Islam is treated primarily as an instrument of political rivalry. The ethnic factor is the prime source of potential and actual tensions. An exception to this is the involvement of Muslim states and Muslim organizations, which in various ways affect the attitudes and opinions of Muslims living in the Republic of Serbia. They do this by providing various types of support for the daily functioning of Muslim orthodox and fundamentalists in the religious dimension, as well as mobilising them during various types of dispute, crises and conflicts. An example of the second of this type of activity was the support given to Bosniacs and Albanians during the wars accompanying the breakup of the Socialist Federal Republic of Yugoslavia, primarily during the civil wars in Bosnia and Kosovo. Saudi Arabia and the United Arab Emirates were particularly active in providing financial support to Muslims from Bosnia and Albania. Consequently, the authorities and services of the Republic of Serbia must be alert to any organizational support for Serbian Muslims that may flow through Bosnia and Herzegovina and through Kosovo and Albania. This issue has a direct impact on the relations of the Republic of Serbia and neighboring states in the context of the Muslim religious minority living in the Republic of Serbia ${ }^{12}$.

${ }^{11}$ M. Korzeniewska-Wiszniewska, op. cit., pp. 172-173; M. Styrczula, Konflikt serbsko-albański w tzw. Dolinie Preszewa i Miedwiedzi, [in:] My już jesteśmy zjedzeni... Rola i znaczenie prawosławia w konflikcie etnicznym w Dolinie Preszewa, ed. R. Zenderowski, Warszawa 2012, pp. 341-342.

${ }^{12} \mathrm{M}$. Ickiewicz-Sawicka, Bośniaccy muzutmanie (Boszniacy) w obliczu kryminogennego i radykalnego islamu na Batkanach - przypadek Bośni i Hercegowiny, [in:] Islam i muzutmanie w kultu- 
A special case in the relations between the Republic of Serbia and neighboring states is Kosovo, which functions in the international arena as a state, but its independence was not recognized by the Republic of Serbia. Both the authorities of the Republic of Serbia and the Serbian society recognize Kosovo as an integral part of their country, as the Autonomous Province of Kosovo and Metohija. Unfortunately, the volume framework of this article does not allow a detailed analysis of the Kosovo situation in international relations. Nonetheless, Kosovo is inhabited mostly by Albanians who profess Islam. In the context of religious problems affecting the relations between the subjects, the greatest of them is the instrumental use of Islam for political purposes by the leaders of the Kosovo Albanians. For the political leaders of the Albanians in Kosovo, Islam is the building block of Kosovo society's identity ${ }^{13}$. This use of Islam has led to intense antagonism from Muslim Albanians, who make up the majority of Kosovo residents from minorities living in Kosovo, both ethnic and religious. The basic "enemy" for the Albanians from Kosovo are the Orthodox Serbs. As a result, Orthodox monasteries, churches and other Christian religious buildings were destroyed by Muslims in Kosovo; these buildings are an important cultural heritage of Serbs and Christians in the territory of Kosovo ${ }^{14}$. Moreover, by capturing the inseparable connection with Islam in the minds of the Kosovo Albanians, in the realities of the political, social and economic situation prevailing in the territory of Kosovo, Kosovo is a convenient base for Muslim fundamentalists ${ }^{15}$.

\section{Summary}

According to official statistics, the Muslim religious minority living in the Republic of Serbia (excluding Kosovo) is a small percentage of the total population of the Republic of Serbia, which is at the level of $3.10 \%$. The number of Muslims in the Republic of Serbia should be considered slightly undervalued, which results from the Muslim boycott of the last census, which was carried out in 2011. Excluding Kosovo, the largest concentrations of Muslim populations occur in individual municipalities of three districts: the Raška District, the

rze, literaturze i językach Stowian Południowych, ed. A. Buras-Marciniak, Łódź 2016, pp. 227-228. More about it: K. Izak, Radykalny islam na Bałkanach źródłem konfliktów społecznych i terrorystycznego zagrożenia dla Europy, „Przegląd Bezpieczeństwa Wewnętrznego” 2013, No. 9(5).

${ }^{13}$ A. Gola, G. Selaci, Socio-political and Religious Dynamics in Kosovo from the Post-Secularist Perspective, „Croatian Political Science Review” 2017, Vol. 54, No. 4, p. 97. More about it: G. Krasniqi, The „Forbidden Fruit”: Islam and Politics of Identity in Kosovo and Macedonia, „Southeast European and Black Sea Studies" 2011, Vol. 11.

${ }^{14}$ P. Czubik, Niepodległość Kosowa - niebezpieczeństwo dla zjednoczonej Europy? Krótki zarys problemu, [in:] Batkany u progu zjednoczonej Europy, ed. P. Czubik, Kraków 2008, p. 136.

${ }_{15}^{15}$ „ICG Balkans Report”, 1.01.2001, No. 105, Religion in Kosovo, Pristina-Brussels 2001, pp. 4-6; P. Petrović, Islamic radicalism in the Balkans, „ISSUE Alert”, 24.06.2016. 
Zlatibor District and the Pčinja District. These are administrative units located at the border with Bosnia and Herzegovina and at the border with Kosovo. It should also be remembered that the Muslim religious minority in the Republic of Serbia is not homogeneous even in a religious case, because it is represented by two religious organizations. They are the Islamic Community in Serbia, with a seat in Novi Pazar, and the Islamic Community of Serbia, with a seat in Belgrade.

The influence of the Muslim religious minority in the Republic of Serbia on the shape of relations between the Republic of Serbia and neighboring states should be considered in two ways, because religious issues are not determinants of this type of relationship. One should remember the inseparable connection of religious issues with ethnic issues and language issues in the Balkan region, and therefore also in Kosovo. For this reason, these factors must also be taken into account in the context of the analysis of the influence of the Muslim religious minority of relations between the Republic of Serbia and neighboring states. Islam is, first and foremost, an instrument of political rivalry between the Republic of Serbia and neighboring states, which mainly concerns relations with Bosnia and Herzegovina and with Kosovo, because the Muslim population living in the Republic of Serbia are mostly of Bosniac or Albanian origin. In addition, Muslim countries and Muslim organizations interfere in SerbianBosnian and Serbian-Albanian relations because they are interested in the situation of Muslims in the Republic of Serbia. The Kosovo problem is particularly sensitive, because there were religiously motivated acts of violence, although the activation of the religious question arose from the political interests of the Kosovo Albanians. 